Hydrol. Earth Syst. Sci., 13, 2359-2371, 2009

www.hydrol-earth-syst-sci.net/13/2359/2009/

(C) Author(s) 2009. This work is distributed under

the Creative Commons Attribution 3.0 License.

\title{
Nitrogen retention in natural Mediterranean wetland-streams affected by agricultural runoff
}

\author{
V. García-García, R. Gómez, M. R. Vidal-Abarca, and M. L. Suárez \\ Department of Ecology and Hydrology, Faculty of Biology, University of Murcia, Campus of Espinardo, 30100 Murcia, Spain
}

Received: 18 June 2009 - Published in Hydrol. Earth Syst. Sci. Discuss.: 6 August 2009

Revised: 25 November 2009 - Accepted: 27 November 2009 - Published: 10 December 2009

\begin{abstract}
Nitrogen retention efficiency in natural Mediterranean wetland-streams affected by agricultural runoff was quantified and the effect of the temporal variability and hydrological/chemical loading was examined from March 2007 to June 2008 in two wetland-streams located in Southeast Spain. Nitrate-N $\left(\mathrm{NO}_{3}^{-}-\mathrm{N}\right)$, ammonium- $\mathrm{N}\left(\mathrm{NH}_{4}^{+}-\mathrm{N}\right)$, total nitrogen- $\mathrm{N}(\mathrm{TN}-\mathrm{N})$, total organic nitrogen-N (TON-N) and chloride $\left(\mathrm{Cl}^{-}\right)$concentrations were analyzed to calculate nitrogen retention efficiencies. These wetland-streams consistently reduced water nitrogen concentration throughout the year with higher values for $\mathrm{NO}_{3}^{-}-\mathrm{N}(72.3 \%)$, even though the mean value of inflow $\mathrm{NO}_{3}^{-}-\mathrm{N}$ concentrations was above $20 \mathrm{mg} \mathrm{l}^{-1}$. Additionally, they usually acted as sinks for TON$\mathrm{N}(8.4 \%)$, but as sources for $\mathrm{NH}_{4}^{+}-\mathrm{N}$. Over the entire study period, the Taray and Parra wetland-streams were capable of removing on average 1.6 and $0.8 \mathrm{~kg} \mathrm{NO}_{3}^{-}-\mathrm{N}$ a day ${ }^{-1}$, respectively. Retention efficiencies were not affected by temperature variation. $\mathrm{NO}_{3}^{-}-\mathrm{N}$ retention efficiency followed a seasonal pattern with the highest retention values in summer (June-September). The temporal variability for $\mathrm{NO}_{3}^{-}-\mathrm{N}$ retention efficiency was positively and negatively explained by the hydrologic retention and the inflow $\mathrm{NO}_{3}^{-}-\mathrm{N}$ concentration $\left(R_{\mathrm{adj}}^{2}=0.815, p<0.01\right)$, respectively. No significant regression model was found for TON-N and $\mathrm{NH}_{4}^{+}-\mathrm{N}$. Finally, the conservation of these Mediterranean wetlandstreams may help to not only improve the surface water quality in agricultural catchments, but to also achieve good ecological status for surface waters, this being the Water Framework Directive's ultimate purpose.
\end{abstract}

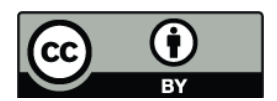

Correspondence to: V. García-García (viquigar@um.es)

\section{Introduction}

Nitrogen is an essential nutrient for aquatic ecosystem functioning. Its variation influences community structure, microbial activity and primary production (Pringle, 1990; Peterson et al., 2001; Dodds et al., 2002). In recent years however, nitrogen $(\mathrm{N})$ concentrations have increased in many areas as a result of human activities and have important negative effects on natural ecosystems (Townsend et al., 2003; Niyogi et al., 2004). Therefore, a great deal of attention has been paid to the movement (fluxes) and transformation of N, especially in streams (Peterson et al., 2001; Kemp and Dodds, 2002; Gücker and Boëchat, 2004).

Agricultural runoff is an important source of non point pollution of aquatic ecosystems, causing eutrophication through nutrient load enrichment (Peterjohn and Correll, 1984; Mitsch et al., 2005). Unlike point source pollution, diffuse pollution is less easily controlled and its reduction can only be achieved by appropriate land management techniques.

Over the last few decades, much interest has been manifested in specific natural systems, such as riparian zones which are able to reduce or buffer the flux of $\mathrm{N}$ from terrestrial to aquatic ecosystems (Lowrance et al., 1984; Groffman et al., 1992; Sabater et al., 2003). In general, wetlands can improve water quality through physical, chemical and biological processes that remove $\mathrm{N}$ from water (HowardWilliams, 1985). This is possible because they have zones of high primary productivity in surface environments and decomposition in sediments that create coupled aerobic and anaerobic transformations of $\mathrm{N}$ molecules that pass through them (Bowden, 1987). The role of wetlands in removing $\mathrm{N}$ from runoff surface waters is globally recognized (Lowrance et al., 1984; Fisher and Acreman, 2004), but the extreme variability of biological and hydrological processes make it difficult to predict the efficiency of $\mathrm{N}$ retention of the different types of wetlands.

Published by Copernicus Publications on behalf of the European Geosciences Union. 
Nitrogen retention efficiency in constructed wetlands has been extensively studied for wetlands to be used in conjunction with agricultural drainage and wastewater treatment systems (Spieles and Mitsch, 2000). However, few studies have analyzed nutrient retention efficiencies in natural wetlands (Jordan et al., 2003; Vellidis et al., 2003; Fisher and Acreman, 2004; Knox et al., 2008), despite some studies demonstrating their utility in water quality control on the catchment scale (Mitsch, 1992; Mitsch et al., 2005; Chavan et al., 2008). Indeed, the European Framework Directive (2000/60/EC) emphasizes the role of wetlands as significant elements of the hydrological networks required to obtain a "good water status" for surface and ground waters (Wetlands Horizontal Guidance, 2003).

In the Southeast Iberian Peninsula (Spain), the presence of small wetland-streams is a typical feature of the Mediterranean landscape of sedimentary catchments (Gómez et al., 2005). These wetlands, which are associated with stream drainage systems, intercept the runoff waters originating from the agricultural catchments in which they are located. This spatial arrangement converts wetland-streams into natural tools to control non point pollution. These agricultural areas are typically fertilized with $\mathrm{N}$ inorganic salts $\left(\mathrm{KNO}_{3}\right)$ with a load of $250-300 \mathrm{~kg} \mathrm{~N} \mathrm{ha}^{-1}$ year $^{-1}$.

Apart from the studies on $\mathrm{N}$ retention in Mediterranean streams (Martí and Sabater, 1996; Sabater et al., 2000; Martí et al., 2004; Von Schiller et al., 2008), there are virtually no studies related with Mediterranean wetlands.

Unlike temperate wetlands, a feature of Mediterranean wetland-streams and other arid and semi-arid aquatic systems is the hydrological intermittency (Gasith and Resh, 1999; Acuña et al., 2005) which strongly influences the structure and functioning of aquatic ecosystems, including $\mathrm{N}$ dynamic (Bernal et al., 2005; Von Schiller et al., 2008; Gómez et al., 2009). Moreover, the $\mathrm{N}$ concentration and water discharge in aquatic systems affected by agricultural runoff inputs likely show wide temporal fluctuations, mainly due to crop irrigation practices. Over longer time scales, the nature and extent of $\mathrm{N}$ input into wetlands will likely affect attenuation processes. By way of example, riparian zones that have been subject to long-term nitrate inputs may have attenuation capacities that differ from non nitrate enriched areas (Groffman et al., 1992). Many studies reported a negative effect of high $\mathrm{N}$ concentrations and discharges on $\mathrm{N}$ retention efficiency in wetlands (Emmett et al., 1994; Spieles and Mitsch, 2000; Knox et al., 2008). In fact, high N concentrations may have a saturation effect on $\mathrm{N}$ microbial and plant uptake (Sabater et al., 2003; Bernot and Dodds, 2005). On the other hand, high water discharges provide short retention times and low surface areas for $\mathrm{N}$ exchange per unit volume of water (Peterson et al., 2001; Pinay et al., 2002).

The two objectives of this study were to quantify the $\mathrm{N}$ $\left(\mathrm{NO}_{3}^{-}-\mathrm{N}, \mathrm{NH}_{4}^{+}-\mathrm{N}, \mathrm{TN}-\mathrm{N}\right.$ and TON-N) retention efficiency in Mediterranean wetland-streams affected by agricultural

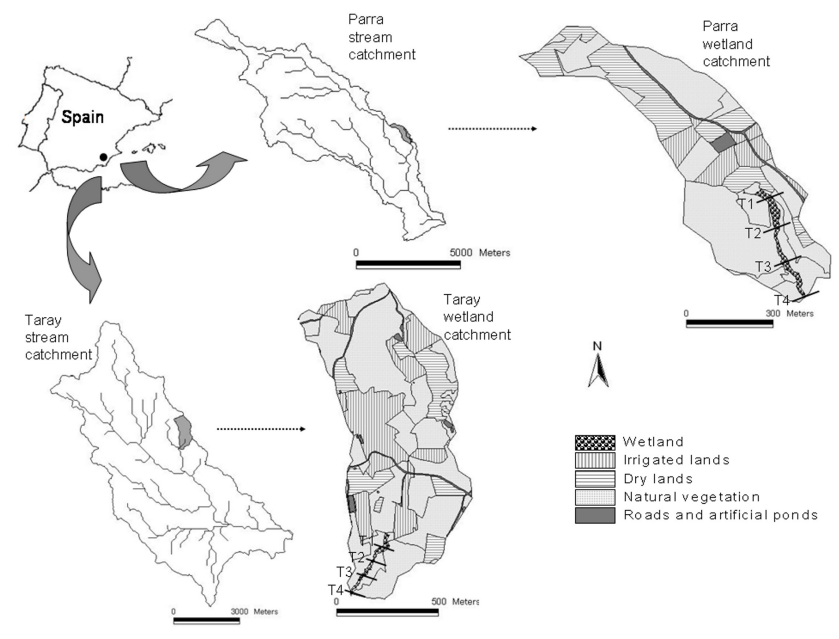

Fig. 1. Location of the studied wetland-streams and their catchments. T1, T2, T3 and T4 represent the four transects on each wetland where samples were collected.

runoff and to examine the effect of the temporal variability and hydrological/chemical loading on $\mathrm{N}$ retention.

An understanding of the $\mathrm{N}$ retention capacity of the Mediterranean wetland-streams receiving agricultural runoff is important for several reasons: it may help to determine the key factors driving $\mathrm{N}$ retention in these systems; it allows better predictions of how $\mathrm{N}$ retention in wetland-streams will vary in response to fluctuations of hydrologic/chemical loading and it allows researchers and managers to design better management plans to control non point pollution in agricultural catchments.

\section{Materials and methods}

\subsection{Study site}

The study was carried out in two natural wetland-streams, the Taray and Parra wetlands, located in the Murcia Region in Southeast Spain (Fig. 1). The climate of the study area is semiarid Mediterranean with temperate winters and hot, dry summers. Average annual precipitation is $300 \mathrm{~mm}$ and the average annual temperature is close to $18^{\circ} \mathrm{C}$.

Wetland-streams are situated at the outlet of small catchments (the mean altitudes are 207 and $172 \mathrm{~m}$ over sea level for the Taray and Parra wetlands, respectively) and collect runoff waters from agricultural lands and natural surrounding areas (Fig. 1, Table 1). Surface water flows through the Taray and Parra wetlands and finally, water leaves them via an intermittent channel that flows into the Salada and Parra streams, respectively (Fig. 1). Both wetland-streams are intermittent with periods of low discharge (usually during summer) or even drought periods. Geomorphological features and discharge data are shown in Tables 1 and 2, respectively. 
Table 1. Surface area, land uses at wetland-stream catchments and geomorphological features recorded in the wetland-streams during the study period.

\begin{tabular}{|c|c|c|}
\hline & Taray & Parra \\
\hline \multicolumn{3}{|l|}{ Wetland-stream catchment } \\
\hline Total area (ha) $)^{\mathrm{a}}$ & 74.5 & 33.2 \\
\hline Irrigated lands $(\%)^{\mathrm{a}, \mathrm{b}}$ & 24.1 & 10.8 \\
\hline Dry lands $(\%)^{\mathrm{a}, \mathrm{c}}$ & 13 & 24.6 \\
\hline Natural vegetation $(\%)^{\mathrm{a}}$ & 60.5 & 61.8 \\
\hline Roads and artificial ponds $(\%)^{\mathrm{a}}$ & 2.4 & 2.8 \\
\hline \multicolumn{3}{|l|}{ Wetland-stream } \\
\hline Total area (ha) $)^{\mathrm{a}}$ & 0.5 & 0.7 \\
\hline Surface flow length (m) & 300 & 300 \\
\hline Surface flow width (m) & $3.4-7.1$ & $2.3-13.4$ \\
\hline Surface flow depth (cm) & $0.5-10$ & $0.5-10$ \\
\hline
\end{tabular}

a Calculated from GIS data.

$\mathrm{b}$ Irrigated lands included fruit trees and vegetables (with irrigation and fertilizer inputs).

${ }^{\mathrm{c}}$ Dry lands included almond and olive trees (without irrigation and fertilizer inputs).

The wetland-streams' catchments are characterized by impermeable sedimentary marls (from the Miocene) with a considerable gypsum content (calcium sulfate) and halite (sodium chloride). As a result of this lithology, water conductivity is very high (Table 2) and wetland-stream sediments have a considerable clay and silt content. Natural vegetation in catchments is scarce and dominated by Mediterranean shrubs, including species like Stippa tenacissima, Lygeum spartum and Thymus hyemalis. Wetland-stream plant communities are composed of helophitic species like Phragmites australis and Juncus maritimus, and halophytic species like Suaeda vera, Arthrocnemum macrostachyum and Sarcocornia fruticosa, in the lower flooded areas. P. australis is located in the upper-part of the wetlands with a plant cover that ranges from $47.2 \%$ to $58.7 \%$ for the Taray and Parra wetlands, respectively. J. maritimus only appears in small patches in the lower part of the Taray wetland. With the exception of small patches of Vaucheria dichotoma, aquatic macrophytes are absent. Periphyton communities are frequent on fine substrates.

\subsection{Methods}

To determine the wetland-stream retention efficiencies for $\mathrm{NO}_{3}^{-}-\mathrm{N}, \mathrm{NH}_{4}^{+}-\mathrm{N}, \mathrm{TN}-\mathrm{N}$ and TON-N, four sampling transects were located on each wetland, perpendicularly to the water flow direction and with a separation of approximately $100 \mathrm{~m}$ (Fig. 2). Sampling transects were opened through vegetation areas to reach the surface water. Surface water samples were collected once a month from the different transects, from March 2007 to March 2008 (13 sampling dates)

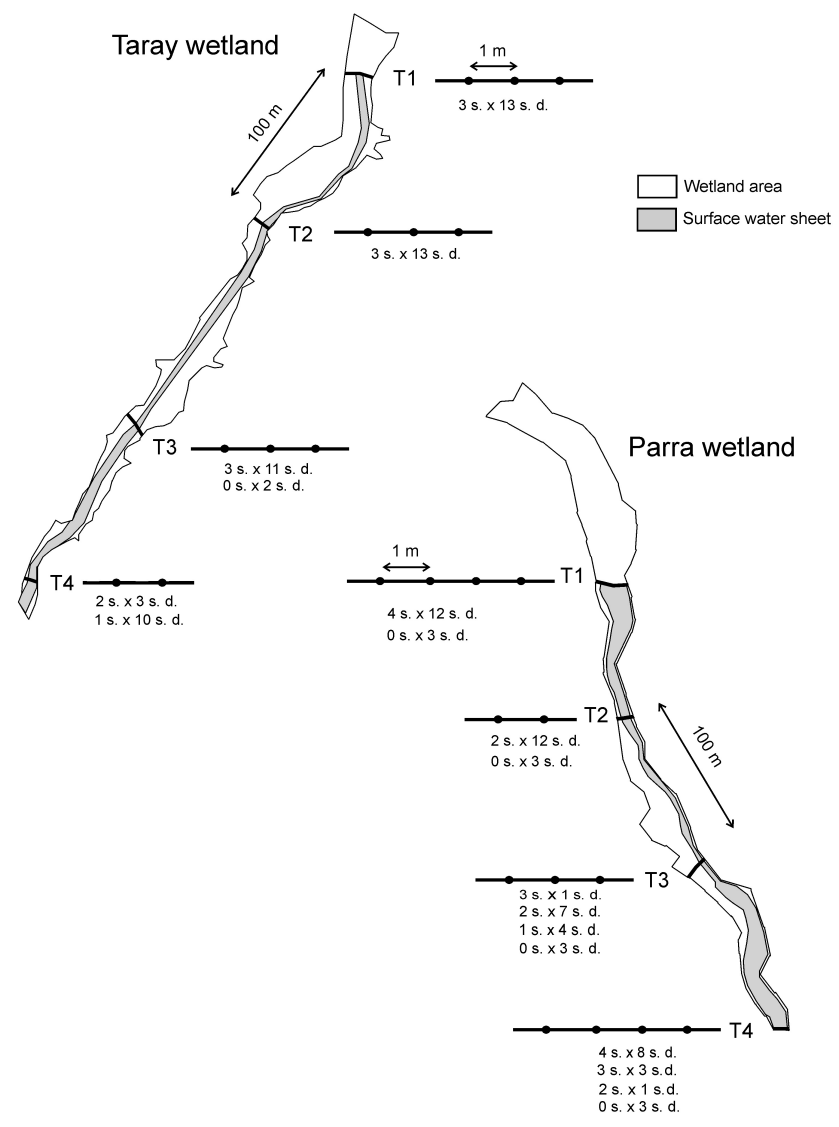

Fig. 2. Location of the four sampled transects in the studied wetland-streams. In each transect (black lines) the number of samples (s.) collected in the different sampling dates (s. d.) are shown. 0 samples mean that the transect was dry.

in the Taray wetland and from April 2007 to June 2008 (15 sampling dates) in the Parra wetland (Fig. 2). The four transects of Parra wetland were dry from July to September 2007, while in the Taray wetland surface water only disappeared in the transect 3 during August and September 2007 (Fig. 2).

Surface water samples were collected with plastic syringes $(100 \mathrm{ml})$ as the water was so shallow (Table 1), and were stored in previously acid-washed polyethylene bottles $(500 \mathrm{ml})$ under dark and cold conditions until they were analyzed at the laboratory. The number of samples per transect varied between 1 and 4, depending on the water sheet width (Fig. 2). The total number of samples per sampling date ranged from 7 to 11 and from 10 to 13 for the Taray and Parra wetlands, respectively. Air and water temperatures, salinity and conductivity (conductivity meter Tetracon 325; WTW, Munich, Germany) and the presence of macrophytes species or periphyton communities were also recorded at each transect.

The outlet discharge was estimated for both wetlandstreams as the product of the average water velocity (current meter MiniAir2; Schiltknecht Co, Zürich, Switzerland) and 
Table 2. Mean, median, 10th and 90th percentile values for solute concentrations, conductivity and temperature of inflow water to wetlandstreams. The inlet/outlet discharges and the net hydrologic retention values are also shown. Inlet discharge values were estimated by Eq. (4) (method section). $n=13$ and $n=12$ in the Taray and Parra wetlands, respectively. ${ }^{*}=(n=11)$.

\begin{tabular}{|c|c|c|c|c|c|c|c|c|}
\hline & \multicolumn{4}{|c|}{ Taray wetland-stream } & \multicolumn{4}{|c|}{ Parra wetland-stream } \\
\hline & Mean & Median & P10 & $\mathrm{P} 90$ & Mean & Median & P10 & $\mathrm{P} 90$ \\
\hline $\mathrm{TN}-\mathrm{N}\left(\mathrm{mg} \mathrm{l}^{-1}\right)$ & 23.9 & 23.6 & 20.8 & 27.4 & 29.7 & 28.7 & 13.6 & 46.9 \\
\hline $\mathrm{NO}_{3}^{-}-\mathrm{N}\left(\mathrm{mg} \mathrm{l}^{-1}\right)$ & 21.5 & 21.4 & 18.4 & 24.4 & 27.4 & 27.1 & 12.7 & 42.8 \\
\hline TON-N $\left(\mathrm{mg} \mathrm{l}^{-1}\right)$ & 2.4 & 2.1 & 0.5 & 4.7 & 2.3 & 0.7 & 0.1 & 7.8 \\
\hline $\mathrm{NH}_{4}^{+}-\mathrm{N}\left(\mathrm{mg} \mathrm{l}^{-1}\right)$ & 0.01 & 0.01 & 0.003 & 0.03 & 0.01 & 0.01 & 0.001 & 0.03 \\
\hline $\mathrm{Cl}^{-}\left(\mathrm{gl}^{-1}\right)$ & 3.2 & 3.3 & 2.9 & 3.5 & 3.5 & 3.5 & 2.5 & 4.3 \\
\hline Conductivity $\left(\mathrm{mS} \mathrm{cm}^{-1}\right)$ & 17.3 & 17.7 & 15.5 & 18.5 & 15.6 & 15.1 & 13.2 & 18.4 \\
\hline Water temperature $\left({ }^{\circ} \mathrm{C}\right)$ & 15.8 & 16.1 & 9.6 & 22 & 14.7 & 14.8 & 10.8 & 17.4 \\
\hline Inlet discharge $\left(1 \mathrm{~s}^{-1}\right)$ & $1^{*}$ & $0.7^{*}$ & $0.1^{*}$ & $2.6^{*}$ & 0.8 & 0.8 & 0.1 & 1.4 \\
\hline Outlet discharge $\left(1 \mathrm{~s}^{-1}\right)$ & $0.6^{*}$ & $0.4^{*}$ & $0.1^{*}$ & $1.4^{*}$ & 0.7 & 0.7 & 0.1 & 1.4 \\
\hline Net hydrologic retention & $0.5^{*}$ & $0.5^{*}$ & $0.4^{*}$ & $0.5^{*}$ & 0.1 & 0.1 & 0.002 & 0.2 \\
\hline
\end{tabular}

the cross-sectional area at the wetland outlets (Transect 4 , Fig. 2). It was not possible to measure the inlet discharge because of the diffuse surface water inputs to the wetlands.

The precipitation data were obtained from the two nearest thermo-pluviometric stations to the studied wetlands (SIAM; Servicio de Información Agrometeorológica, Región de Murcia), Fortuna station that was located approximately $0.4 \mathrm{~km}$ from Taray wetland and Abanilla station that was located approximately $5.5 \mathrm{~km}$ from Parra wetland.

\subsection{Chemical analyses}

Water samples were analyzed for $\mathrm{N}$ dissolved forms within $24 \mathrm{~h}$ of collection. They were filtered through glass-fiber filters (Whatman GF/C, $1.2 \mu \mathrm{m}$ nominal pore size; Whatman International Ltd., Maidstone, England). $\mathrm{NO}_{3}^{-}-\mathrm{N}$ concentration was measured by a colorimetric method following cadmium reduction to nitrite- $\mathrm{N}\left(\mathrm{NO}_{2}^{-}-\mathrm{N}\right)$ (Wood et al., 1967). $\mathrm{NO}_{2}^{-}-\mathrm{N}$ concentration was analyzed by diazotization (Strickland and Parsons, 1972). $\mathrm{NO}_{3}^{-}-\mathrm{N}$ concentration was estimated by subtracting the $\mathrm{NO}_{2}^{-}-\mathrm{N}$ concentration obtained by diazotization. $\mathrm{NH}_{4}^{+}-\mathrm{N}$ concentration was measured by the phenyl-hypochlorite colorimetric method (Solorzano, 1969). Dissolved inorganic nitrogen (DIN) was calculated as the sum of the $\mathrm{NO}_{3}^{-}-\mathrm{N}, \mathrm{NO}_{2}^{-}-\mathrm{N}$ and $\mathrm{NH}_{4}^{+}-\mathrm{N}$ concentrations.

Total nitrogen concentration (TN-N) was measured on unfiltered and frozen samples. These samples were digested to $\mathrm{NO}_{3}^{-}-\mathrm{N}$ using potassium persulfate (D'Elia, 1977) and were analyzed by cadmium reduction using an automated ion analyzer (EasyChem Plus, Systea Analytical Technologies, Italy). TON-N concentration was estimated by subtracting the DIN concentration from the TN-N concentration. Chloride concentration $\left(\mathrm{Cl}^{-}\right)$was analyzed within $48 \mathrm{~h}$ of collection by the silver nitrate volumetric method (APHA, 1985).

\subsection{Retention calculations}

Chloride was used to calculate $\mathrm{N}$ retention in the wetlandstreams (e.g. Simmons et al., 1992; Sabater et al., 2003). As a passive tracer, $\mathrm{Cl}^{-}$undergoes dispersion, dilution and diffusion, but is not significantly removed from solutions and consequently, its movements largely track water flow. Thus, the variations in $\mathrm{Cl}^{-}$concentration allow the detection of possible dilution (by lateral or subsurface water inputs) or solute concentration (by evapotranspiration) that also affects $\mathrm{N}$ forms.

An input-output nutrient budget for a wetland depends on a hydrological budget which in simple terms we assumed for the studied wetland-streams as $\mathrm{SW}_{\text {in }}=\mathrm{E}+\mathrm{SW}_{\text {out }}$, where $\mathrm{SW}_{\text {in }}$ is the inflow surface water, $\mathrm{E}$ is the evapotranspiration and $\mathrm{SW}_{\text {out }}$ is the outflow surface water. With the exception of evapotranspiration as a water output, we assumed no hydrological inputs and outputs through the studied wetlandstreams. Piezometric levels and subsurface $\mathrm{Cl}^{-}$concentration data (not showed in this paper) together with the surface water $\mathrm{Cl}^{-}$concentrations suggested that groundwater inputs (shallow subsurface flow sources) and outputs (surface water infiltration) through the stream-wetlands were negligible. Only in two occasions (August and September 2007, in the Taray wetland), surface water was infiltrated (T3) but few meters downwetland it went back into the wetland surface (before T4).

Thus, retention efficiency (\%R) was calculated for the different $\mathrm{N}$ forms $\left(\mathrm{NO}_{3}^{-}-\mathrm{N}, \mathrm{NH}_{4}^{+}-\mathrm{N}, \mathrm{TN}-\mathrm{N}\right.$ and TON-N) on each sampling date by considering, Eq. (1) (Trudell et al., 1986):

$\% \mathrm{R}=\left(1-\left(\mathrm{N} / \mathrm{Cl}_{\text {out }}^{-} / \mathrm{N} / \mathrm{Cl}_{\text {in }}^{-}\right)\right) \times 100$

$\mathrm{N} / \mathrm{Cl}_{\text {in }}^{-}$and $\mathrm{N} / \mathrm{Cl}_{\text {out }}^{-}$are the concentration ratios of both solutes in the inlet (T1) and outlet (T4) of both 
wetland-streams, respectively. Although to estimate $\mathrm{N}$ retention were only used $\mathrm{N}$ and $\mathrm{Cl}^{-}$data registered in $\mathrm{T} 1$ and $\mathrm{T} 4$, data from the rest of sampling transects (T2 and T3) were used to check any possible water input and to control the applicability of the used equations (described above and below).

$\% \mathrm{R}$ is the percentage of the $\mathrm{N}$ removed by the wetlands in relation to the inflow of $\mathrm{N}$. A positive retention value indicates that the inflow $\mathrm{N} / \mathrm{Cl}^{-}$ratio was higher than the outflow $\mathrm{N} / \mathrm{Cl}^{-}$ratio. Under this circumstance wetland-streams were $\mathrm{N}$ sinks. On the contrary, a negative retention value indicates that the outflow $\mathrm{N} / \mathrm{Cl}^{-}$ratio was higher than the inflow $\mathrm{N} / \mathrm{Cl}^{-}$ratio and wetland-streams were $\mathrm{N}$ sources. The outflow $\mathrm{N}$ load $\left(\mathrm{mg} \mathrm{N} \mathrm{day}^{-1}\right)$ was calculated as the product of outflow $\mathrm{N}$ concentration $\left(\mathrm{mg}^{-1}\right)$ by outlet discharge $\left(1 \mathrm{~s}^{-1}\right)$. Under the previously described assumption, the percentage of retention (\%R) was applied to the outflow $\mathrm{N}$ load to estimate the inflow $\mathrm{N}$ load $\left(\mathrm{mg} \mathrm{N}\right.$ day $\left.^{-1}\right)$. The $\mathrm{N}$ net removal was calculated as follows:

Nitrogen net removal $=$ inflow $\mathrm{N}$ load - outflow $\mathrm{N}$ load

Finally, the net hydrologic retention for each sampling date in both wetland-streams was calculated by considering, Eq. (3), used by Stanley and Ward (1997):

Net hydrologic retention $=$

(inlet discharge - outlet discharge)/inlet discharge

The net hydrologic retention was estimated as an indirect measurement of the water residence time inside the wetland. Positive values of the net hydrologic retention $(<1)$ indicate that the discharge diminishes as surface water flows through the wetland and as a consequence, the water velocity diminishes and the water residence time increases. The net hydrologic retention is 1 when the wetland is dry. If the discharge does not change through the wetland, the net hydrologic retention is 0 . A negative value indicates that the outlet discharge is higher than the inlet discharge as result of surface or subsurface water inputs. Because it was not possible to measure the inlet discharge, due to the diffuse water inputs to the wetlands, this was calculated for each sampling date as follows:

Inlet discharge $\left(1 \mathrm{~s}^{-1}\right)=$ outlet discharge $* \mathrm{Cl}_{\text {out }}^{-} / \mathrm{Cl}_{\text {in }}^{-}$

\subsection{Statistical analyses}

The coefficient of variation (CV) for inflow $\mathrm{N}$ concentrations and retention efficiencies was used as an indicator of their temporal variability throughout study period. The relationship between $\mathrm{N}$ retention efficiency and the physical, chemical and hydrological parameters was evaluated using Spearman correlations with the SPSS software rel.15.0.1 for Windows (SPSS Incorporated, Chicago, Illinois). Seasonal differences in $\mathrm{N}$ retention were analyzed using analysis of variance (one-way ANOVA), followed by
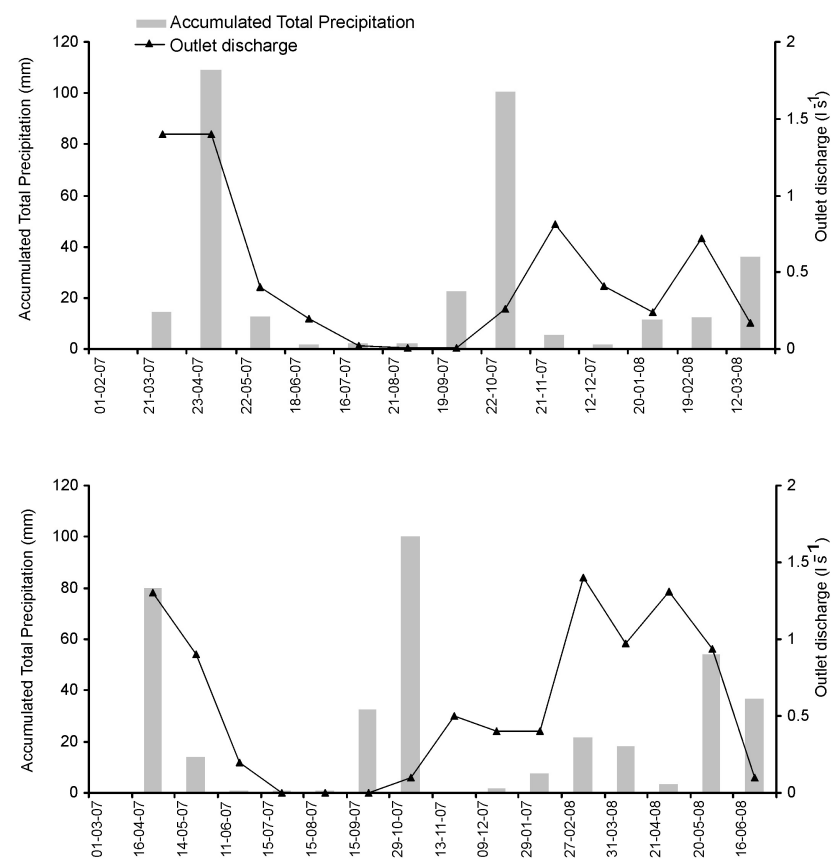

Fig. 3. Accumulated total precipitation (between consecutive sampling dates) and outlet discharge registered during the study period in the (a) Taray and (b) Parra wetland-streams.

Tukey's post-hoc test with the SPSS software. Months were grouped as follows: spring (March-May), summer (June-September), autumn (October-November) and winter (December-February). Multiple linear regression analyses were used to calculate the best fitting regression model that explains the $\mathrm{N}$ retention in the studied wetland-streams. The percentages of $\mathrm{NO}_{3}^{-}-\mathrm{N}$ retention were transformed prior to regression analysis with the arcsin transformation $y=\arcsin (\sqrt{p})$, where $p$ is the percentage expressed as a proportion, in the range $0-1$. The transformed variable $(y)$ was fitted to the multiple regression analysis. Arcsin transformation is usually applied to binomial data in order to approximate normal variance. However, our purpose here was to bind the limits of prediction by multiple regression into the bounds $0-1(0-100 \%)$ as the result of transforming back to original units is constrained to the range $0-1$. Not transforming the variable may result on the unrealistic case of multiple regression predicting $>100 \%$ retention, in some cases. The multiple linear regression analyses were performed with R rel.2.6.0 for Windows (R Development Core Team, Vienna, Austria).

\section{Results}

\subsection{Inflow water characterization}

Figure 3 shows the variation of accumulated total precipitation between consecutive sampling dates and the outlet discharge in both wetland-streams during the study period. 
Table 3. Concentration, load, net removal, and retention efficiency for $\mathrm{TN}-\mathrm{N}, \mathrm{NO}_{3}^{-}-\mathrm{N}$, TON-N, and $\mathrm{NH}_{4}^{+}-\mathrm{N}$ registered at inflows and outflows of the wetland-streams. Values are the mean \pm standard deviation based on the data collected over the study period $(n=13$ and $n=12$ in the Taray and Parra wetlands, respectively). ${ }^{*}=(n=11)$.

\begin{tabular}{|c|c|c|c|c|c|c|c|}
\hline & \multicolumn{2}{|c|}{ Concentration $\left(\mathrm{mg} \mathrm{l}^{-1}\right)$} & \multicolumn{3}{|c|}{ Load $\left(\mathrm{mg} \mathrm{m}^{-2} \mathrm{~d}^{-1}\right)$} & \multirow{2}{*}{$\begin{array}{c}\text { Retention } \\
\text { efficiency }(\%)\end{array}$} & \multirow{2}{*}{$\begin{array}{l}\text { Median retention } \\
\text { efficiency }(\%)\end{array}$} \\
\hline & Inflow & Outflow & Inflow & Outflow & Net removal & & \\
\hline \multicolumn{8}{|c|}{ Taray wetland-stream } \\
\hline TN-N & $23.9 \pm 2.4$ & $5.4 \pm 2.5$ & $428 \pm 383^{*}$ & $72 \pm 84^{*}$ & $356 \pm 309^{*}$ & $87.9 \pm 7$ & 88.2 \\
\hline $\mathrm{NO}_{3}^{-}-\mathrm{N}$ & $21.5 \pm 1.9$ & $3.8 \pm 2.7$ & $378 \pm 321^{*}$ & $54 \pm 58^{*}$ & $324 \pm 269^{*}$ & $90.4 \pm 7.4$ & 89.5 \\
\hline TON-N & $2.4 \pm 1.4$ & $1.6 \pm 1.1$ & $49.3 \pm 68.5^{*}$ & $18 \pm 27.5^{*}$ & $31.3 \pm 48.3^{*}$ & $43.9 \pm 69.7$ & 71.2 \\
\hline $\mathrm{NH}_{4}^{+}-\mathrm{N}$ & $0.013 \pm 0.01$ & $0.02 \pm 0.02$ & $0.11 \pm 0.08^{*}$ & $0.08 \pm 0.08^{*}$ & $0.03 \pm 0.06^{*}$ & $11 \pm 85.6$ & 31 \\
\hline \multicolumn{8}{|c|}{ Parra wetland-stream } \\
\hline TN-N & $29.7 \pm 10.4$ & $17.1 \pm 10$ & $307.5 \pm 251.9$ & $186.8 \pm 176.1$ & $120.7 \pm 81.5$ & $50.9 \pm 21.9$ & 36.4 \\
\hline $\mathrm{NO}_{3}^{-}-\mathrm{N}$ & $27.4 \pm 10.2$ & $15.4 \pm 9.4$ & $287.4 \pm 237$ & $171.6 \pm 162$ & $115.8 \pm 79$ & $52.8 \pm 22.6$ & 39.8 \\
\hline TON̈-N & $2.3 \pm 3$ & $1.6 \pm 2$ & $19.8 \pm 29.6$ & $14.9 \pm 22$ & $4.9 \pm 15.4$ & $-30 \pm 151$ & 19.6 \\
\hline $\mathrm{NH}_{4}^{+}-\mathrm{N}$ & $0.013 \pm 0.016$ & $0.016 \pm 0.008$ & $0.14 \pm 0.3$ & $0.13 \pm 0.11$ & $0.01 \pm 0.2$ & $-213.4 \pm 447.6$ & -49.04 \\
\hline
\end{tabular}

Temporal variability of the accumulated total precipitation was high and the maximum values were registered mainly in months of spring and fall (March, April and October). The outlet discharge also differed vastly between study months $(\mathrm{CV}=87.7 \%$ and $68.2 \%$ in the Taray and Parra wetlands, respectively) but their highest and lowest values did not always correspond with increases or decreases in the precipitation, respectively. Despite the high temporal variability of the outlet discharges, the mean values in both wetland-streams were similar (Table 2).

Table 2 compiles the physicochemical characterization of the inflow water in the wetland-streams during the study period. Although the mean value for inflow TN-N concentration was higher in the Parra than in the Taray wetland (Table 2), the relative contribution of $\mathrm{N}$ forms in the inflow water was similar in both wetlands $(90.4 \%, 9.5 \%, 0.1 \%$ and $92.6 \%$, $7.3 \%, 0.1 \%$ as $\mathrm{NO}_{3}^{-}-\mathrm{N}$, TON-N and $\mathrm{NH}_{4}^{+}-\mathrm{N}$, respectively). The highest variability in the range of inflow $\mathrm{N}$ concentrations throughout the study period corresponded to the Parra wetland.

The inflow $\mathrm{NO}_{3}^{-}-\mathrm{N}$ concentrations in the Taray wetland were consistently similar throughout the study period $(\mathrm{CV}=8.6 \%, n=13)$, while a higher temporal variability was noted for the Parra wetland $(\mathrm{CV}=37.1 \%, n=12)$ (Fig. 4). This difference between both wetland-streams was mainly influenced by the sharp increase of inflow $\mathrm{NO}_{3}^{-}-\mathrm{N}$ concentration (30-43 $\mathrm{mg}^{-1}$ ) registered from March to June 2008 in the Parra wetland (Fig. 4). The inflow TON-N and $\mathrm{NH}_{4}^{+}-\mathrm{N}$ concentrations varied considerably among the study months (Fig. 4). The CV values for TON-N were 58.0\% $(n=13)$ and $131.3 \%(n=12)$ in the Taray and Parra wetlands respectively and were $83.6 \%(n=13)$ and $117.2 \%(n=12)$ for $\mathrm{NH}_{4}^{+}-\mathrm{N}$.

The mean value for inflow $\mathrm{Cl}^{-}$concentration was high and similar in both wetland-streams (Table 2). $\mathrm{As}_{3}^{-}-\mathrm{N}$, inflow
$\mathrm{Cl}^{-}$concentrations were similar throughout the study period in the Taray wetland $(\mathrm{CV}=6.7 \%, n=13)$, while they showed a greater temporal variability in the Parra wetland $(\mathrm{CV}=17.6$, $n=12$ ) (Fig. 4). On the other hand, decreases of the inflow $\mathrm{Cl}^{-}$concentration generally coincided with increases of the inflow $\mathrm{NO}_{3}^{-}-\mathrm{N}$ concentration in the Parra wetland (Fig. 4).

The mean value of the net hydrologic retention was higher in the Taray wetland than in the Parra wetland (Table 2), while their temporal variability was higher in the Parra wetland $(\mathrm{CV}=84 \%, n=12)$ than in the Taray wetland $(\mathrm{CV}=14 \%$, $n=11)$.

\subsection{Nitrogen retention efficiencies}

When all the sampling data from both wetland-streams were considered, the mean retention efficiency for TN-N was $70.1 \%$ (median value $=82.9 \%, n=25$ ) and it was higher in the Taray than in the Parra wetland (Table 3). Both wetlandstreams showed the highest retention efficiency for $\mathrm{NO}_{3}^{-}-\mathrm{N}$, followed by TON-N and $\mathrm{NH}_{4}^{+}-\mathrm{N}$ (Table 3). The mean retention efficiency for $\mathrm{NO}_{3}^{-}-\mathrm{N}$ was $72.3 \%$ (median value $=84 \%$, $n=25$ ), ranging from $31.7 \%$ to $100 \%$. However, the mean retention efficiency and net removal for $\mathrm{NO}_{3}^{-}-\mathrm{N}$ was consistently higher in the Taray wetland than in the Parra wetland (Table 3).

The retention efficiency for TON-N was low with a mean value of $8.4 \%$ (median value $=56.1 \%, n=25$ ) and ranged from $-437 \%$ to $99.5 \%$. The mean retention efficiency and the net removal were significantly higher in the Taray wetland than in Parra wetland (Table 3). There was not removal of TON-N from the water of both wetland-streams on 6 of the 25 sampling dates, as show the existence of negative retention values (Fig. 5). On these occasions, the TON-N/Clratio was higher at the outlet than at the inlet of both wetlandstreams, denoting TON-N exportation. 

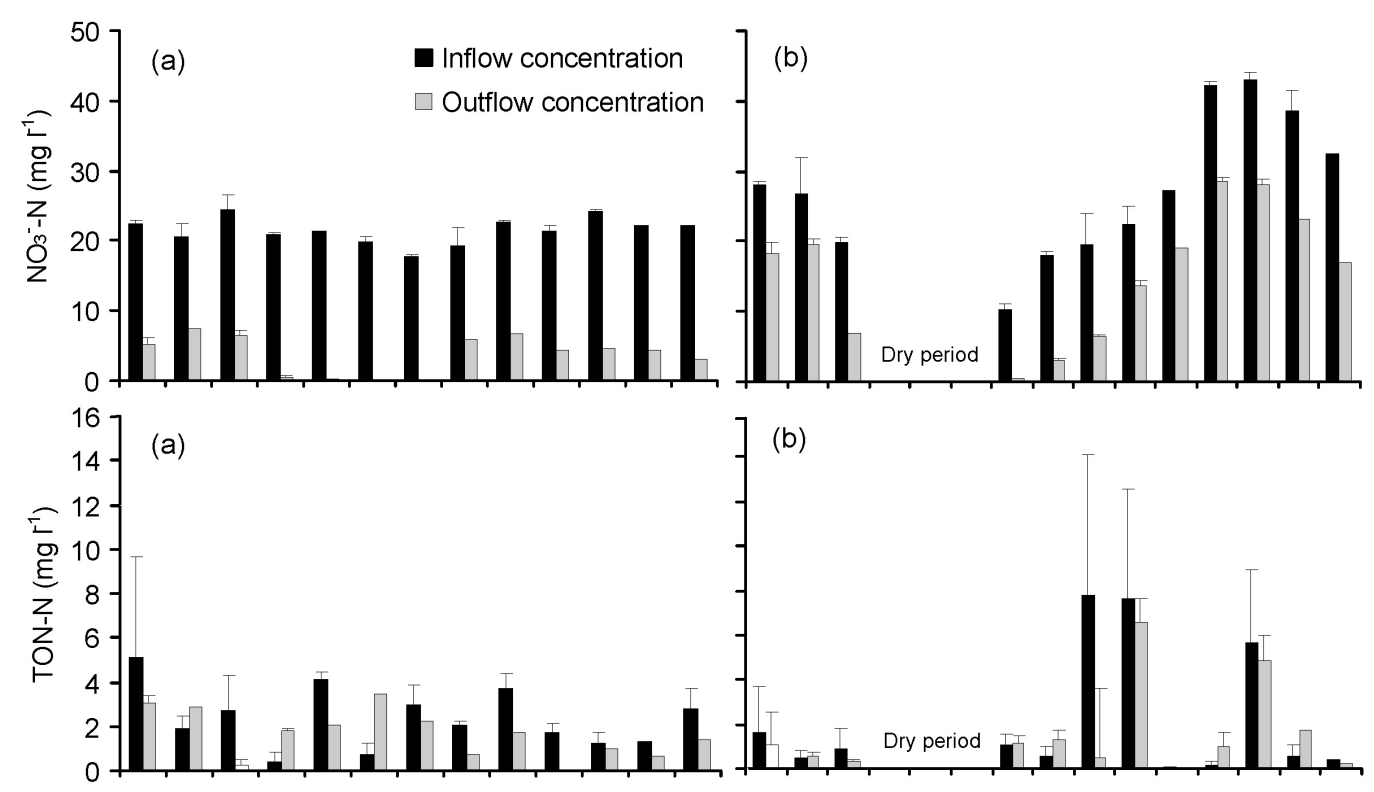

(b)

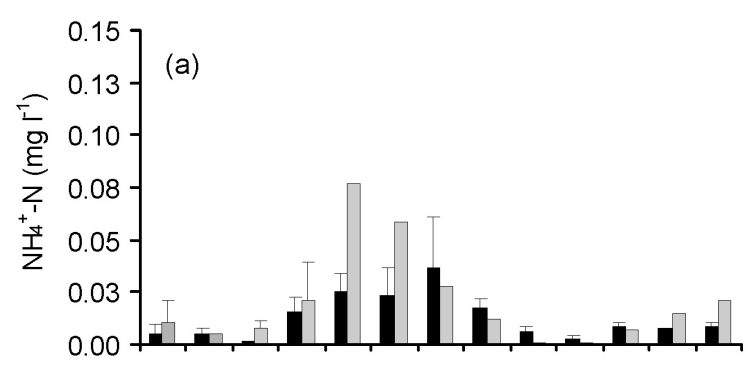

(b)

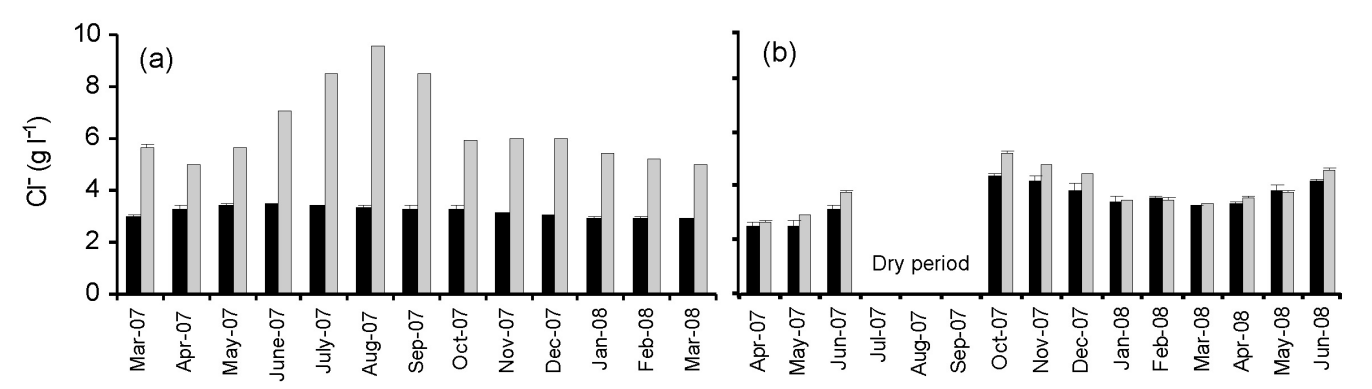

Fig. 4. Temporal variation of the inflow/outflow $\mathrm{NO}_{3}^{-}-\mathrm{N}, \mathrm{TON}-\mathrm{N}, \mathrm{NH}_{4}^{+}-\mathrm{N}$ and $\mathrm{Cl}^{-}$mean concentrations $(+\mathrm{SD})$ in the (a) Taray and (b) Parra wetland-streams, over the study period.

Ammonium-N was not removed from water, but was exported instead on the majority of the sampling dates (13 of 25) (Fig. 5). The mean retention efficiency was $-96.7 \%$ (median value $=-3.2 \%, n=25$ ), ranging from $-1537.5 \%$ to $96.0 \%$. As same as for TON-N, the mean retention efficiency was only positive in the Taray wetland and the net removal was also higher in this wetland (Table 3 ).

\subsection{Temporal variability of $\mathrm{N}$ retention efficiencies}

The temporal variability of the retention efficiencies for $\mathrm{NO}_{3}^{-}-\mathrm{N}$ was higher in the Parra wetland than in the Taray wetland; $\mathrm{CV}=42.7 \%(n=12)$ and $\mathrm{CV}=8.2 \%(n=13)$, respectively (Fig. 5). Retention efficiencies for $\mathrm{NO}_{3}^{-}-\mathrm{N}$ increased during the summer (June-September) in both wetlandstreams (Fig. 5). However, differences among seasons were only statistically significant in the Taray wetland (one-way ANOVA, $F=29.9, p<0.05$ ). The scarcity of data during summer in the Parra wetland (drought period) could be the reason of the absent of statistical significance for this wetland. The maximum $\mathrm{NO}_{3}^{-}-\mathrm{N}$ retention values $(99.9 \%$ and 96.0\%) were recorded in August and October in the Taray and Parra wetlands, respectively (Fig. 5). 


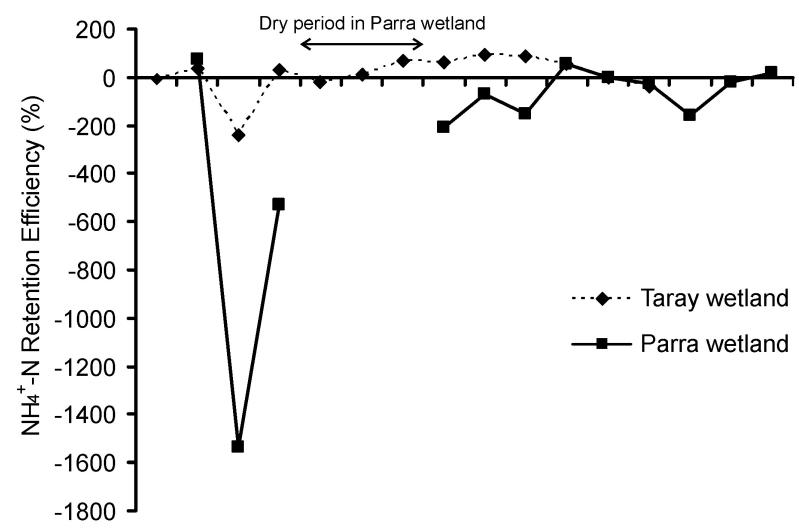

\subsection{Effect of environmental factors on $\mathbf{N}$ retention efficiencies}

Table 4 shows the results of the Spearman correlations performed to evaluate the relationship between $\mathrm{N}$ retention efficiency and different environmental factors: inlet discharge, hydrologic retention, inflow $\mathrm{N}$ concentration, inflow load, and water and air temperatures.

The strongest relationship found was between $\mathrm{NO}_{3}^{-}-\mathrm{N}$ retention efficiency and net hydrologic retention, which was positive (Table 4). TON-N retention efficiency was also positively correlated with the net hydrologic retention (Table 4). In contrast, $\mathrm{NH}_{4}^{+}-\mathrm{N}$ retention efficiency was not correlated with this variable (Table 4).

Nitrate-N retention efficiency was negatively correlated with the inflow $\mathrm{NO}_{3}^{-}-\mathrm{N}$ concentration and the inlet discharge, whereas TON-N and $\mathrm{NH}_{4}^{+}-\mathrm{N}$ retention efficiencies were positively correlated with the inflow TON-N and $\mathrm{NH}_{4}^{+}-\mathrm{N}$ concentrations, respectively (Table 4).

Finally, the multiple linear regression analysis showed that $81.5 \%$ of temporal variability for the $\mathrm{NO}_{3}^{-}-\mathrm{N}$ retention efficiency was explained by the net hydrologic retention and the inflow $\mathrm{NO}_{3}^{-}-\mathrm{N}$ concentration. This model was positive for the net hydrologic retention and negative for the inflow $\mathrm{NO}_{3}^{-}$$\mathrm{N}$ concentration with a high level of significance $\left(\mathrm{NO}_{3}^{-}-\mathrm{N}\right.$ retention efficiency $=(\operatorname{sen}(1.149+0.948 *$ net hydrologic retention $-0.015 *$ inflow $\mathrm{NO}_{3}^{-}-\mathrm{N}$ concentration) $)^{2} ; R_{\text {adj }}^{2}=0.815$, $p<0.01, n=25)$. Significant regression models were not obtained for TON-N and $\mathrm{NH}_{4}^{+}-\mathrm{N}$.

\section{Discussions}

\subsection{Nitrogen retention efficiencies}

This study shows that Mediterranean wetland-streams affected by agricultural inputs can remove efficiently TN-N from water. The retention efficiency was strongly influenced by $\mathrm{N}$ speciation in agreement with previous studies (Spieles and Mitsch, 2000; Vellidis et al., 2003; Knox et al., 2008).

Wetland-streams have showed most efficient for removing $\mathrm{NO}_{3}^{-}-\mathrm{N}$ from water, the dominant $\mathrm{N}$ form, but were less efficient for the removal of TON-N and $\mathrm{NH}_{4}^{+}-\mathrm{N}$. The studied wetlands were sinks for $\mathrm{TN}-\mathrm{N}$ and $\mathrm{NO}_{3}^{-}-\mathrm{N}$ during all the study period, while they were sources for TON-N and $\mathrm{NH}_{4}^{+}$$\mathrm{N}$ under some circumstances. Several studies have shown the ability of wetlands to remove $\mathrm{NO}_{3}^{-}-\mathrm{N}$ from water. Knox et al. (2008) found a mean retention efficiency for $\mathrm{NO}_{3}^{-}-\mathrm{N}$ of $60.0 \%$ in a natural flow-through wetland of California with a Mediterranean climate that collected agricultural runoff whose mean $\mathrm{NO}_{3}^{-}-\mathrm{N}$ concentration was $0.2 \mathrm{mg} \mathrm{l}^{-1}$. Jordan et al. (2003) showed that a restored wetland removed $52.0 \%$ of the $\mathrm{NO}_{3}^{-}-\mathrm{N}$ received from agricultural runoff whose usual $\mathrm{NO}_{3}^{-}$-N concentration values were $<1 \mathrm{mg} \mathrm{l}^{-1}$. In the studied 
Table 4. Results of Spearman correlations between the retention efficiencies (\%R) of the different nitrogen forms and the environmental factors by considering the dataset registered during the study period in both wetland-streams.

\begin{tabular}{|c|c|c|c|}
\hline & $\mathrm{NO}_{3}^{-}-\mathrm{N} \% \mathrm{R}$ & TON-N \%R & $\mathrm{NH}_{4}^{+}-\mathrm{N} \% \mathrm{R}$ \\
\hline & $\mathrm{r}$ & $\mathrm{r}$ & $\mathrm{r}$ \\
\hline Inlet discharge $\left(1 \mathrm{~s}^{-1}\right)$ & $-0.419^{*}$ & -0.099 & 0.221 \\
\hline Net hydrologic retention & $0.834^{* *}$ & $0.429^{*}$ & 0.244 \\
\hline Inflow $\mathrm{NO}_{3}^{-}-\mathrm{N}$ concentration $\left(\mathrm{mg} \mathrm{l}^{-1}\right)$ & $-0.655^{* *}$ & & \\
\hline Inflow TON-N concentration $\left(\mathrm{mg} \mathrm{l}^{-1}\right)$ & & $0.519^{* *}$ & \\
\hline Inflow $\mathrm{NH}_{4}^{+}-\mathrm{N}$ concentration $\left(\mathrm{mg} \mathrm{l}^{-1}\right)$ & & & $0.429^{*}$ \\
\hline Inflow $\mathrm{NO}_{3}^{-}-\mathrm{N}$ load $\left(\mathrm{g} \mathrm{m}^{-2} \mathrm{~d}^{-1}\right)$ & -0.370 & & \\
\hline Inflow TON-N load $\left(\mathrm{g} \mathrm{m}^{-2} \mathrm{~d}^{-1}\right)$ & & 0.095 & \\
\hline Inflow $\mathrm{NH}_{4}^{+}-\mathrm{N}$ load $\left(\mathrm{g} \mathrm{m}^{-2} \mathrm{~d}^{-1}\right)$ & & & 0.083 \\
\hline Water temperature $\left({ }^{\circ} \mathrm{C}\right)$ & 0.256 & -0.196 & -0.258 \\
\hline Air temperature $\left({ }^{\circ} \mathrm{C}\right)$ & 0.125 & -0.146 & -0.282 \\
\hline
\end{tabular}

* Significant at the 0.05 probability level.

** Significant at the 0.01 probability level.

wetland-streams, the mean retention efficiency for $\mathrm{NO}_{3}^{-}-\mathrm{N}$ $(72.3 \%)$ was higher than that found in these aforementioned studies, even though the mean inflow concentration for $\mathrm{NO}_{3}^{-}$$\mathrm{N}$ was above $20 \mathrm{mg}^{-1}$. Besides, other studies performed in constructed wetlands generally show lower retention efficiencies for $\mathrm{NO}_{3}^{-} \mathrm{N}$ than our results (Spieles and Mitsch, 2000; Braskerud, 2002; Mitsch et al., 2005). By considering both the annual mean inflow load of $\mathrm{NO}_{3}^{-}-\mathrm{N}$ and the annual mean retention efficiency, the Taray and Parra wetlandstreams were capable of removing mean values of 1.6 and $0.8 \mathrm{~kg}$ of $\mathrm{NO}_{3}^{-}-\mathrm{N}$ a day ${ }^{-1}$, respectively.

Denitrification, biological uptake and microbial immobilization are the main mechanisms for $\mathrm{NO}_{3}^{-}-\mathrm{N}$ removal in wetlands (Reddy and Patrick, 1984; Bowden, 1987; Groffman et al., 1992). These processes are influenced by the hydrologic conditions of wetlands (De Laune et al., 1981; Bowden, 1987; Pinay et al., 2007). In the studied wetlandstreams, $\mathrm{NO}_{3}^{-}-\mathrm{N}$ retention efficiency was negatively correlated with the inlet discharge and positively correlated with net hydrologic retention, thus suggesting that longer water residence times allow a longer time for $\mathrm{NO}_{3}^{-}-\mathrm{N}$ removal from surface water. Nutrient retention in wetlands is governed not only by changes in the hydrographs, but also by both the flow-through (velocity) and water residence time rates (Howard-Williams, 1985). If water moves through a wetland at a quicker rate than that of $\mathrm{N}$ retention processes (denitrification or biological uptake), then considerable flow-through of $\mathrm{N}$ will take place. Peverly (1982) found that wetlands only retained nutrients when flow-through rates were low, while Stanley and Ward (1997) observed that net retention for all the $\mathrm{N}$ forms was strongly correlated with hydrological retention in the Talladega Wetland Ecosystem (TWE, Alabama, USA).
On the other hand, several authors have reported that denitrification may be potentially important in aquatic systems dominated by fine sediments, high $\mathrm{NO}_{3}^{-}-\mathrm{N}$ and organic carbon availability, a low redox potential of sediments, and warm water temperature (Faulkner and Richardson, 1989; García-Ruiz et al., 1998; Inwood et al., 2007; Pinay et al., 2007). Unlike organic matter (and N) accumulation, which conserves $\mathrm{N}$ within the wetland, denitrification represents a permanent $\mathrm{N}$ loss from the system. Natural wetland sediments are chemically reduced and frequently contain ample organic carbon. Therefore, denitrification in wetlands is generally limited by nitrate availability (Ambus and Lowrance, 1991). Nonetheless, this is not the case of the wetlands affected by agricultural inputs. Therefore, although denitrification was not estimated in the studied wetland-streams, this process is proposed to be an important pathway for $\mathrm{NO}_{3}^{-}$$\mathrm{N}$ loss because its occurrence is consistent with their environmental characteristics (high $\mathrm{NO}_{3}^{-}-\mathrm{N}$ availability, high water temperature, anoxic-black sediments and high hydrologic retention).

The retention capacity of wetlands varies seasonally, particularly in temperate regions where biological activity diminishes in winter (Howard-Williams, 1985; Groffman et al., 1992). In fact, studies performed in these regions show that $\mathrm{NO}_{3}^{-}-\mathrm{N}$ retention efficiency is controlled mainly by the temperature (Spieles and Mitsch, 2000; Chavan et al., 2008). In the studied wetland-streams, $\mathrm{NO}_{3}^{-}-\mathrm{N}$ retention efficiency tended to increase in summer months although significant differences among seasons were only observed in the Taray wetland (the lack of statistical significance for Parra wetland may be explained by the absence of data from July to September 2007, during the drought period). However, in contrast with the previously mentioned studies, we did not find correlation between $\mathrm{NO}_{3}^{-}-\mathrm{N}$ retention efficiency and 
temperature in the studied wetland-streams. One suggestion to explain the lack of correlation between both variables is that the warm temperate climate of the study area enables the continuous operation of the essential biogeochemical processes involved in $\mathrm{NO}_{3}^{-}-\mathrm{N}$ removal. This lack of correlation reinforces the fact that Mediterranean wetland-streams can significantly remove $\mathrm{N}$ input. We attributed the increase of $\mathrm{NO}_{3}^{-}-\mathrm{N}$ retention efficiency during the summer months to optimum hydrological conditions, as high net hydrologic retention rates, that favour $\mathrm{N}$ proccesing in wetlands (mainly biological uptake and denitrification). The increases of $\mathrm{Cl}^{-}$ concentrations during the summer months support the idea of evapotranspiration as the responsible factor of the hydrologic retention increases in the studied wetland-streams.

Wetland-streams acted as sinks for TON-N during most of the study period with net removal mean values of 153.9 and $34.4 \mathrm{~g} \mathrm{a} \mathrm{day}^{-1}$ for Taray and Parra wetlands, respectively. However, they were also sources for TON-N in some occasions. Similar results were obtained by other authors. For example, Jordan et al. (2003) reported TON-N retention efficiencies ranging from $-15.0 \%$ to $39.0 \%$.

TON-N retention in the studied wetland-streams, as same as in other wetlands, could be greater than the values obtained by input-output balance. Leaching and decomposition of autochthonous particulate organic matter is an additional source of organic $\mathrm{N}$ and decreases net TON-N retention. Decomposition of litter is probably the major source of TON-N in our wetland-streams, as other studies reported (HowardWilliams, 1985; Bowden, 1987; Chapman et al., 2001). In fact, some of these studies show that TON-N concentrations are generally higher in summer and fall and suggest increases relate to the autochthonous litter decomposition or to primary production. In contrast, no seasonal pattern was observed in our wetlands study. Bernal et al. (2005) also reported the absence of such a pattern in TON-N retention for an intermittent Mediterranean stream.

As same as previous studies (Braskerud, 2002), TON-N retention efficiency was positively correlated with the inflow TON-N concentration. In addition, it was positively correlated with the net hydrologic retention, probably because the sedimentation of the organic matter associated with soil particles and the processing rates of TON-N to inorganic forms were higher under greater residence time of water within the wetlands (Jordan et al., 2003).

The studied wetland-streams were usually net sources of $\mathrm{NH}_{4}^{+}-\mathrm{N}$ over the study period. However, when wetlandstreams occasionally retained $\mathrm{NH}_{4}^{+}-\mathrm{N}$, their retention values were relatively high in comparison with those of previous studies. For example, Braskerud (2002) showed a mean retention value of $1.0 \%$ in small constructed wetlands that treat agricultural non-point source pollution. We suggest that litter decomposition and mineralization are the main autochthonous sources of $\mathrm{NH}_{4}^{+}-\mathrm{N}$ in wetland-streams. Once wetland vegetation has died, a large and complex series of nutrient transformations emerges, all of which are associated with the leaching of detritus and simultaneous decomposition (Howard-Williams, 1985). Several studies have demonstrated that plant detritus processing may be an important source of nutrients (Howarth and Fisher, 1976; MacLean and Wein, 1978). Kinetic mineralization of TON-N probably proceeds more rapidly than nitrification, thus $\mathrm{NH}_{4}^{+}-\mathrm{N}$ concentration increases in surface water (Kadlec and Knight, 1996; Braskerud, 2002).

On the other hand, $\mathrm{NH}_{4}^{+}-\mathrm{N}$ is more sensitive than $\mathrm{NO}_{3}^{-}-\mathrm{N}$ to slight changes of local conditions (chemical, physical and biological variables) (Hill, 1996; Butturini and Sabater, 1998; Gücker and Boëchat, 2004), which also change as flow discharge does (Fisher et al., 1998; Von Schiller et al., 2008). Furthermore, $\mathrm{NH}_{4}^{+}-\mathrm{N}$ reacts abiotically via adsorption/desorption reactions, and displays processing lengths that reflect the nature of the sediments and the chemical environment (Triska et al., 1994). Both properties are spatially heterogeneous in wetlands, and this variability increases as flow discharge decreases (Gücker and Boëchat, 2004), which also occurs close to wetland-stream outlets. Thus, slight changes in the sediment redox potential may not only affect the exchange of $\mathrm{NH}_{4}^{+}-\mathrm{N}$ at the water-sediment interface, but may also influence the $\mathrm{NH}_{4}^{+}-\mathrm{N}$ concentration in surface water (De Laune et al., 1981; Bowden, 1987). The fact that $\mathrm{NH}_{4}^{+}-\mathrm{N}$ retention efficiency was lower than that for $\mathrm{NO}_{3}^{-}-\mathrm{N}$, and that it was even exported from wetland-streams, is consistent with this idea.

The temporal variability of the $\mathrm{NH}_{4}^{+}-\mathrm{N}$ retention was very high in this study and was only positively correlated with the inflow $\mathrm{NH}_{4}^{+}$-N concentration. However, Sabater et al. (2000) showed that $83.0 \%$ of the seasonal variation in the $\mathrm{NH}_{4}^{+}-\mathrm{N}$ retention efficiency in a Mediterranean stream without riparian vegetation is explained by water temperature. The lack of correlation between other environmental factors and $\mathrm{NH}_{4}^{+}-\mathrm{N}$ retention in the studied wetland-streams may be explained by the high sensitivity of $\mathrm{NH}_{4}^{+}-\mathrm{N}$ concentration to slight changes of the local conditions (sediment redox potential, organic matter content, etc.) as we previously suggested.

\subsection{Influence of the hydrologic retention and the inflow $\mathrm{N}$ concentration on the $\mathrm{NO}_{3}^{-}-\mathrm{N}$ retention efficiency}

The main factors controlling the $\mathrm{NO}_{3}^{-}-\mathrm{N}$ retention efficiency in the studied wetland-streams are the hydrologic retention and the inflow $\mathrm{NO}_{3}^{-}-\mathrm{N}$ concentration. We hypothesized that a higher hydrologic retention increases $\mathrm{NO}_{3}^{-}-\mathrm{N}$ retention efficiency through an increase of biological processing rates (as biological uptake and denitrification).

Net hydrologic retention was used as an indirect measurement of the water residence time in wetland-streams. This factor often influences the $\mathrm{N}$ retention in aquatic systems because a longer contact time between surface water and 
sediment implies that the total amount of processed $\mathrm{N}$ increases (Peterson et al., 2001; Gücker and Boëchat, 2004).

Inflow $\mathrm{NO}_{3}^{-}-\mathrm{N}$ concentration was the second factor controlling the $\mathrm{NO}_{3}^{-}-\mathrm{N}$ retention in the studied wetlandstreams. Other studies in both, riparian buffers and natural/constructed wetlands, report a similar relationship between both variables (e.g. Spieles and Mitsch, 2000; Sabater et al., 2003). In addition, these authors suggest a saturation effect by a high $\mathrm{NO}_{3}^{-}-\mathrm{N}$ load which exceeds the buffering capacity of these systems. Although the inflow $\mathrm{NO}_{3}^{-}-\mathrm{N}$ concentrations registered during the study period were high, they never exceeded the loading capacity of the wetlandstreams, as high $\mathrm{NO}_{3}^{-}-\mathrm{N}$ retention rates indicated. Because almost $100 \%$ of $\mathrm{NO}_{3}^{-}-\mathrm{N}$ retention efficiency is obtained with even high inflow $\mathrm{NO}_{3}^{-}-\mathrm{N}$ concentrations (e.g. $99.5 \%$ with $21.4 \mathrm{mg} \mathrm{l}^{-1}$ ), the retention efficiencies could not increase at lower inflow concentrations. Lower inflow $\mathrm{NO}_{3}^{-}-\mathrm{N}$ concentrations than $10.3 \mathrm{mgl}^{-1}$ would be necessary to know the wetland-stream response to low $\mathrm{N}$ concentrations.

\section{Conclusions}

Our results emphasize the high efficiency of Mediterranean wetland-streams as $\mathrm{N}$ sinks all year round. This feature is influenced by low water discharges and probably, by the warm climate, both of which are key factors that make Mediterranean wetland-streams especially interesting compared to temperate wetlands. Wetland-streams consistently reduced $\mathrm{NO}_{3}^{-}-\mathrm{N}$ concentration, the dominant $\mathrm{N}$ form, throughout the year. They usually acted as sinks for TON-N and as sources for $\mathrm{NH}_{4}^{+}-\mathrm{N}$. Hydrological retention and inflow $\mathrm{NO}_{3}^{-}-\mathrm{N}$ concentrations were the main factors explaining the variability in $\mathrm{NO}_{3}^{-}-\mathrm{N}$ removal efficiency. However factors explaining TON-N and $\mathrm{NH}_{4}^{+}-\mathrm{N}$ retention were not found. $\mathrm{NO}_{3}^{-}-\mathrm{N}$ retention showed a seasonal pattern but not directly associated with the temperature, but with the hydrological retention. The highest $\mathrm{NO}_{3}^{-}-\mathrm{N}$ retention effienciencies were detected during summer when evapotranspiration increased and as a consequence, wetland discharge decreased. Stream-wetlands showed a high effiency in $\mathrm{N}$ removal even at high $\mathrm{N}$ concentrations $\left(21.4 \mathrm{mg} \mathrm{l}^{-1}\right)$. Our study in the Taray and Parra wetlands clearly demonstrates the crucial role of Mediterranean wetland-streams in the control of the $\mathrm{N}$ flux from agricultural landscapes to aquatic ecosystems located downstream.

The studied wetland-streams consistently reduce the $\mathrm{N}$ load, in such a way that the water leaving the wetlands is always of better quality than that entering them. In some countries, surface flow wetlands are highly valued for their high nutrient retention potential and their unique biodiversity. However, despite the high efficiency of the Mediterranean wetland-streams to improve surface water quality, they are often desiccated for new agricultural purposes. Presently, there are an increasing number of activities aimed at restoring these sites as multifunctional landscape entities. In fact, there are studies which focus on identifying the most suitable areas for the restoration of surface flow wetlands to improve the water quality of a given catchment (Mitsch, 1992). The wide distribution and strategic location of the Mediterranean wetland-streams in upstream reaches of basins makes them more interesting as special preservation ecosystems. Our results highlight the conservation interest of Mediterranean wetland-streams for two reasons, to protect wetland biodiversity and to improve the surface water quality in agricultural catchments in accordance with WFD's objective (2000/60/EC).

Acknowledgements. We thank Carmen Domínguez and the researchers of this group for their field and laboratory assistance. Special thanks to J. F. Calvo and G. González-Barberá for their assistance with the statistic analyses, to F. Carreño and J. Miñano for their assistance with the graphic edition and to Helen Warburton for her assistance in the English corrections. This research was supported by the project CGL2006-08134 from the Spanish Ministry of Science and Education and by a pre-doctoral grant to V. García García from the CAM (Mediterranean Savings bank).

Edited by: A. Ghadouani

\section{References}

Acuña, V., Muñoz, I., Giorgi, A., Omella, M., Sabater, F., and Sabater, S.: Drought and postdrought recovery cycles in an intermittent Mediterranean stream: structural and functional aspects, J. N. Am. Benthol. Soc., 24, 919-933, 2005.

Ambus, P. and Lowrance, R.: Comparison of denitrification in two riparian soils, Soil Sci. Soc. Am. J., 55, 994-997, 1991.

APHA (American Public Health Association): Standard methods for the examination of water and wastewater, 16th edition, APHA, Washington, DC, 1985.

Bernal, S., Butturini, A., and Sabater, F.: Seasonal variations of dissolved nitrogen and DOC: DON ratios in an intermittent Mediterranean stream, Biogeochemistry, 75, 351-372, 2005.

Bernot, M. J. and Dodds, W. K.: Nitrogen retention, removal, and saturation in lotic ecosystems, Ecosystems, 8, 442-453, 2005.

Bowden, W. B.: The biogeochemistry of nitrogen in freshwater wetlands, Biogeochemistry, 4, 313-348, 1987.

Braskerud, B. C.: Factors affecting nitrogen retention in small constructed wetlands treating agricultural non-point source pollution, Ecol. Eng., 18, 351-370, 2002.

Butturini, A. and Sabater, F.: Ammonium and phosphate retention in a Mediterranean stream: hydrological versus temperature control, Can. J. Fish. Aquat. Sci., 55, 1938-1945, 1998.

Chapman, P. J., Edwards, A. C., and Cresser, M. S.: The nitrogen composition of streams in upland Scotland: some regional and seasonal differences, Sci. Total Environ., 265, 65-83, 2001.

Chavan, P. V., Dennett, K. E., Marchand, E. A., and Spurkland, L. E.: Potential of constructed wetland in reducing total nitrogen loading into the Truckee River, Wetlands Ecol. Manage., 16, 189-197, 2008. 
De Laune, R. D., Reddy, C. N., and Patrick Jr., W. H.: Effect of pH and Redox Potential on Concentration of Dissolved Nutrients in an Estuarine Sediment, J. Environ. Qual., 10, 276-279, 1981.

D'Elia, C. F., Stendler, P. A., and Corwin, N.: Determination of total nitrogen in aqueous samples using persulfate digestion, Limnol. Oceanog., 22, 760-764, 1977.

Dodds, W. K., López, A. J., Bowden, W. B., Gregory, S., Grimm, N. B., Halmilton, S. K., Hershey, A. E., Martí, E., McDowell, W. H., Meyer, J. L., Morall, D., Mulholland, P. J., Peterson, B. J., Tank, J. L., Valett, H. M., Webster, J. R., and Wollheim, W.: $\mathrm{N}$ uptake as a function of concentration in streams, J. N. Am. Benthol. Soc., 21, 206-220, 2002.

Emmett, B. A., Hudson, J. A., Coward, P. A., and Reynolds, B.: The impact of a riparian wetland on streamwater quality in a recently afforested upland catchment, J. Hydrol., 162, 337-353, 1994.

Faulkner, S. P. and Richardson, C. J.: Physical and chemical characteristics of freshwater wetland soils, in: Constructed Wetlands for wastewater treatment, edited by: Hammer, D. A., Lewis Publishers, Chelsea, Michigan, 41-72, 1989.

Fisher, S. G., Grimm, N. B., Martí, E., and Gómez, R. Hierarchy, spatial configuration and nutrient cycling in a desert stream, Aust. J. Ecol., 23, 41-52, 1998.

Fisher, J. and Acreman, M. C.: Wetland nutrient removal: a review of the evidence, Hydrol. Earth Syst. Sci., 8, 673-685, 2004, http://www.hydrol-earth-syst-sci.net/8/673/2004/.

García-Ruiz, R., Pattinson, S. N., and Whitton, B. A.: Denitrification in river sediments: relationship between process rate and properties of water and sediment, Freshwat. Biol., 39, 467-476, 1998.

Gasith, A. and Resh, V. H.: Streams in Mediterranean climate regions: abiotic influences and biotic responses to predictable seasonal events, Annu. Rev. Ecol. Syst., 30, 51-81, 1999.

Gómez, R., Hurtado, I., Suárez, M. L., and Vidal-Abarca, M. R.: Ramblas in south-east Spain: threatened and valuable ecosystems, Aquat. Conserv. Mar. Freshwat. Ecosyst., 15, 387-402, 2005.

Gómez, R., García, V., Vidal-Abarca, R., and Suárez, L.: Effect of intermittency on $\mathrm{N}$ spatial variability in an arid Mediterranean stream, J. N. Am. Benthol. Soc., 28, 572-583, 2009.

Groffman, P. T., Gold, A. J., and Simmons, R. C.: Nitrate dynamics in riparian forest: microbial studies, J. Environ. Qual., 21, 666$671,1992$.

Gücker, B. and Boëchat, I. G.: Stream morphology controls ammonium retention in tropical headwaters, Ecology, 85, 2818-2827, 2004.

Hill, A. R.: Nitrate removal in stream riparian zones, J. Environ. Qual., 25, 743-755, 1996.

Howard-Williams, C.: Cycling and retention of nitrogen and phosphorus in wetlands a theoretical and applied perspective, Freshwat. Biol., 15, 391-431, 1985.

Howarth, R. W. and Fisher, S. G.: Carbon, nitrogen, and phosphorus dynamics during leaf decay in nutrient-enriched stream microecosystems, Freshwater Biol., 6, 221-228, 1976.

Inwood, S. E., Tank, J. L., and Bernot, M. J.: Factors controlling sediment denitrification in Midwestern streams of varying land use, Microb. Ecol., 53, 247-258, 2007.

Jordan, T. E., Whigham, D. F., Hofmockel, K. H., and Pittek, M. A.: Nutrient and sediment removal by a restored wetland receiving agricultural runoff, J. Environ. Qual., 32, 1534-1547, 2003.
Kadlec, R. H. and Knight, R. L.: Treatment wetlands, Lewis Publishers, New York, 1996.

Kemp, M. J. and Dodds, W. K.: The influence of ammonium, nitrate and dissolved oxygen concentrations on uptake, nitrification, and denitrification rates associated with prairie stream substrata, J. N. Am. Benthol. Soc., 47, 1380-1393, 2002.

Knox, A. K., Dahlgren, R. A., Tate, K. W., and Atwill, E. R.: Efficacy of natural wetlands to retain nutrient, sediment and microbial pollutants, J. Environ. Qual., 37, 1837-1846, 2008.

Lowrance, R., Todd, R., Fail, J., Hendrickson Jr., O., Leonard, R., and Asmussen, L.: Riparian forests as nutrient filters in agricultural watersheds, BioScience, 34, 374-377, 1984.

MacLean, D. A. and Wein, R. W.: Weight loss and nutrient changes in decomposing litter and forest floor material in New Brunswick forest stand, Can. J. Botany, 56, 2730-2749, 1978.

Martí, E. and Sabater, F.: High variability in temporal and spatial nutrient retention in Mediterranean streams, Ecology, 77, 854869, 1996.

Martí, E., Aumatell, J., Godé, L., Poch, M., and Sabater, F.: Nutrient retention efficiency in streams receiving inputs from wastewater treatment plants, J. Environm. Qual., 33, 285-293, 2004.

Mitsch, W. J.: Landscape design and the role of created, restored, and natural riparian wetlands in controlling nonpoint source pollution, Ecol. Eng., 1, 27-47, 1992.

Mitsch, W. J., Day, J. W., Zhang, L., and Lane, R. R.: Nitratenitrogen retention in wetlands in the Mississippi River Basin, Ecol. Eng., 24, 267-278, 2005.

Niyogi, D. K., Simon, K. S., and Townsend, C. R.: Land use and stream ecosystem functioning: nutrient uptake in streams that contrast in agricultural development, Archiv. Hydrobiol., 160, 471-486, 2004.

Peterjohn, W. T. and Correl, D. L.: Nutrient dynamics in an agricultural watershed: observations on the role of a riparian forest, Ecology, 65, 1466-1475, 1984.

Peterson, B. J., Wollheim, W. M., Mulholland, P. J., Webster, J. R., Meyer, J. L., Tank, J. L., Martí, E., Bowden, W. B., Valett, H. M., Hershey, A. E., McDowell, W. H., Dodds, W. K., Hamilton, S. K., Gregory, S., and Morrall, D. D.: Control of nitrogen export from watersheds by headwater streams, Science, 292, 8690, 2001.

Peverly, J. H.: Stream transport of nutrients through a wetland, J. Environ. Qual., 11, 38-43, 1982.

Pinay, G., Clément, J. C., and Naiman, R. J.: Basic principles and ecological consequences of changing water regimes on nitrogen cycling in fluvial systems, Environ. Manage., 30, 481-491, 2002.

Pinay, G., Gumiero, B., Tabacchi, E., Gimenez, O., TabacchiPlanty, A. M., Hefting, M. M., Buró, T. P., Black, V. A., Nilsson, C., Iordache, V., Bureau, F., Vought, L., Petts, G. E., and Décamps, H.: Patterns of denitrification rates in European alluvial soils under various hydrological regimes, Freshwat. Biol., 52, 252-266, 2007.

Pringle, C. M.: Nutrient spatial heterogeneity: effects on the community structure, diversity and physiognomy of lotic algal communities, Ecology, 71, 905-920, 1990.

R Development Core Team: R: A language and environment for statistical computing. Release 2.6.0, R Foundation for Statistical Computing, Vienna, Austria, 2007. 
Reddy, K. R. and Patrick, W. H.: Nitrogen transformations and loss in flooded soils and sediments, Crit. Rev. Environ. Control, 13, 273-309, 1984.

Sabater, F., Butturini, A., Martí, E., Muñoz, I., Romaní, A., Wray, J., and Sabater, S.: Effects of riparian vegetation removal on nutrient retention in a Mediterranean stream, J. N. Am. Benthol. Soc., 19, 609-620, 2000.

Sabater, S., Butturini, A., Clément, J. C., Burt, T., Dowrick, D., Hefting, M., Maître, V., Pinay, G., Postolache, C., Rzepecki, M., and Sabater, F.: Nitrogen removal by riparian buffers along a European climatic gradient: patterns and factors of variation, Ecosystems, 6, 20-30, 2003.

Simmons, R. C., Gold, A. J., and Groffman, P. M.: Nitrate dynamics in riparian forest: groundwater studies, J. Environ. Qual., 21, 659-665, 1992.

Solorzano, L.: Determination of ammonia in natural waters by the phenolhypochlorite method, Limnol. Oceanogr., 14, 799-801, 1969.

Spieles, D. J. and Mitsch, W. J.: The effects of season and hydrologic and chemical loading on nitrate retention in constructed wetlands: a comparison of low- and high-nutrient riverine systems, Ecol. Eng., 14, 77-91, 2000.

SPSS Incorporated: SPSS (Statistical Product and Service Solutions) for Windows, Release 15.0.1, SPSS Inc., Chicago, IL, 2006.

Stanley, E. H. and Ward, A. K.: Inorganic nitrogen regimes in an Alabama wetland, J. N. Am. Benthol. Soc., 16, 820-832, 1997.

Strickland, J. D. and Parsons, T. R.: A practical handbook of seawater analysis, Bull. Fish. Res. Board Can., 167, 1-310, 1972.
Townsend, A. R., Howarth, R. W., Bazzaz, F. A., Booth, M. S., Cleveland, C. C., Collinge, S. K., Dobson, A. P., Epstein, P. R., Holland, E. A., Keeney, D. R., Mallin, M. A., Rogers, C. A., Wayne, P., and Wolfe, A. H.: Human health effects of a changing global nitrogen cycle, Front. Ecol. Environ., 1, 240-246, 2003.

Triska, F. J., Jackman, A. P., and Avanzino, R. J.: Ammonium sorption to channel and riparian sediments: a transient storage pool for dissolved inorganic nitrogen, Biogeochemistry, 26, 67-83, 1994.

Trudell, M. R., Gillham, R. W., and Cherry, J. A.: An in-situ study of the occurrence and rate of denitrification in a shallow unconfined sand aquifer, J. Hydrol., 83, 251-268, 1986.

Vellidis, G., Lowrance, R., Gay, P., and Hubbard, R. K.: Nutrient transport in a restored riparian wetland, J. Environ. Qual., 32, 711-726, 2003.

Von Schiller, D., Martí, E., Riera, J. L., Ribot, M., Argerich, A., Fonollá, P., and Sabater, F.: Inter-annual, annual and seasonal variation of $\mathrm{P}$ and $\mathrm{N}$ retention in a perennial and an intermittent stream, Ecosystems, 11, 670-687, 2008.

Wetlands Horizontal Guidance: Draft Horizontal Guidance Document on the Role of Wetlands in the Water Framework Directive, Common Implementation Strategy for the Water Framework Directive (2000/60/EC), 65 pp., 2003.

Wood, E. D., Armstrong, F. A., and Richards, F. A.: Determination of nitrate in seawater by cadmium-copper reduction to nitrate, J. Mar. Biol. Assoc., 47, 23-31, 1967. 